\title{
Occult hepatitis B virus infection in maintenance hemodialysis patients: prevalence and mutations in "a" determinant
}

\section{Yun Tang}

Department of Nephrology, Sichuan Academy of Medical Sciences and Sichuan Provincial People's Hospital, School of Medicine, University of Eletronic Science and Technology of China

\section{Xiangqin Liu}

Sichuan Academy of Medical Sciences and Sichuan People's Hospital

\section{Daqing Hong}

Sichuan Academy of Medical Sciences and Sichuan People's Hospital

\section{Xiangheng Lu}

Nanchang University

\section{Qiang He}

Sichuan Academy of Medical Sciences and Sichuan People's Hospital

\section{Guisen Li}

Sichuan Academy of Medical Sciences and Sichuan People's Hospital

\section{Yang Zou ( $12844995 @ q q . c o m$ )}

Sichuan Academy of Medical Sciences and Sichuan People's Hospital

\section{Research article}

Keywords: maintenance hemodialysis, occult hepatitis B virus infection, amino acid mutation

Posted Date: September 10th, 2019

DOI: https://doi.org/10.21203/rs.2.14206/v1

License: (1) (1) This work is licensed under a Creative Commons Attribution 4.0 International License. Read Full License

Version of Record: A version of this preprint was published at International Journal of Medical Sciences on January 1st, 2020. See the published version at https://doi.org/10.7150/ijms.49540. 


\section{Abstract}

Background $\mathbb{X} \mathrm{Occult}$ hepatitis $\mathrm{B}$ virus infection $(\mathrm{OBI})$ is rare and its diagnosis is often overlooked, but there is still a risk of $\mathrm{HBV}$ transmission. To analysis the prevalence of $\mathrm{OBI}$ among maintenance hemodialysis (MHD) patients in Sichuan Provincial People's Hospital, the molecular biological characteristics of OBI and the mutation of "a" determinant were investigated.

Method: A total of 330 patients undergoing hemodialysis at Sichuan Provincial People's Hospital and its satellite dialysis units were tested for HBV markers by ELISA. HBV-DNA was detected by real-time PCR in patients with HBsAg negative/ HBcAb positive to investigate the prevalence of $\mathrm{OBI}$. For plasma samples with persistent HBV DNA positive, the $S$ gene was determined by nested PCR, and the sequence of gene mutation was compared with the standard sequence.

Result: Among 330 patients, ages range from 27 to 95 with a mean of 60.66 years old and majority of patients $(57.6 \%)>60$ years old. Serum from 165 of $180 \mathrm{HBsAg}$ negative/HBcAb positive individuals were tested for HBV DNA by real-time PCR. 7 of 165 patients had low level of HBV DNA. Of those, 5 individuals were both HBcAb and HBsAb positive, and 2 individuals were HBcAb positive alone. After 2 years followup, 2 individuals with HBcAb positive alone were both tested HBV DNA again, but the other patients were not. Serum from the 2 patients were used nested PCR to confirm the genotype and the mutation of $S$ gene. We found they both were genotype B. Amino acid sequencing confirmed that one had no mutations and the other one had Q128R, T131N, M133S, F134L and D144E mutants in "a" determinant.

Conclusion: Chronic HBV infection was 7.3\% (24/330) and OBI was 2.1\% (7/330) in our hospital

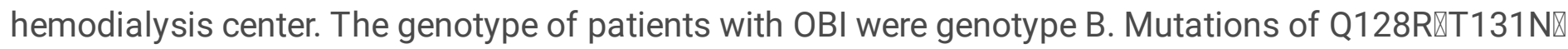
M133S $\mathrm{F} 134 \mathrm{~L}$ and D144E might be the potential sites associated with OBI.

\section{Background}

Chronic hepatitis $\mathrm{B}(\mathrm{CHB})$ infection is highly prevalent in China. The prevalence of HBV sero-epidemiology from national survey was $7.18 \%$ in the year of 2012[1,2]. From Chinese national renal data system, the infection rate specialized in Sichuan province is about $11 \%$. As for hemodialysis patients, the prevalence of $\mathrm{CHB}$ ranged from $11 \%$ to $15 \%$ in developing countries, higher than developed countries[3, 4]. $\mathrm{HBsAg}$ positive has long been considered the marker to diagnosis HBV infection. But in the early study, donors containing anti-HBc but lack of HBsAg led to HBV infection of recipient during blood transfusion[5, 6]. Thus, occult hepatitis $B$ infection $(\mathrm{OBI})$ which is characterized by the presence of HBV DNA in the plasma or liver of people with undetectable HBsAg was proposed[7]. Amount of evidence indicates that OBI may be potentially related to acute hepatitis, cirrhosis and hepatocellular carcinoma(HCC) $[8,9]$. OBI frequently occurs in specific situations including hemodialysis, organ transplantation, chronic liver disease and blood transfusion $[9,10]$. Hemodialysis (HD) patients are more possible incidence of infections as a result of the long-term blood transfusion, the potential exposure to contaminated HD machines, the immunocompromised body, as well as cross-contamination[3, 11-13]. Besides, OBI could be a source of 
infection both to other patients and staff inside the hemodialysis units[13]. The prevention of CHB and $\mathrm{OBI}$ in maintenance hemodialysis patients remains a challenge.

The progression of the disease and the consequences of long-term infection are related to the genotypes and mutations of HBV. The most common type of HBV strains in western countries are genotype $A$ and $D$, whereas those in Asia Pacific region including China are genotypes $B$ and $C$, which possibly lead to different degree of disease progression [2,14].

The main hydrophilic region (MHR) is a highly conserved region on HBsAg encoded by HBV S gene, containing antigenic determinant genes, which can induce the immune response to produce protective anti-HBs. The 124-147 aa sequence in the MHR region is relatively conserved, forming the "a" determinant, which can maintain the antigenicity of the surface antigen. The mutation or substitution at single or multiple sites can lead to changes in amino acids, which is generally believed to impair HBsAg secretion and inhibit the production of anti-HBs[9, 15].

Reports of many studies have described G145R/A, G119R, P120T, M133T/L, T140L, D144E, T131N, T126N mutants around the world [16-24]. Koyanagi analyzed a strain of RBA and used ELISA to detect HBsAg-negative HBV S gene, and found mutations such as G145A and E129N in the "a" determinant caused the appearance of glycosylation sites, which affecting the HBsAg antigenicity[25]. Present studies revealed that mutations are mainly concentrated in the "a" determinant.

This study reports on the prevalence and molecular characteristics of OBI among MHD patients in Sichuan Provincial People's Hospital. The research focus on exploring HBV-related biomarkers from studies on genomics to further improve the efficacy of antiviral therapy.

\section{Methods}

\section{Study design and patients}

The study conducted 330 adult patients undergoing hemodialysis more than three months at Sichuan provincial people's hospital and its satellite dialysis units from December, 2014 to December, 2015. A systematic screening of HBV sero-markers were detected by ELISA (PerkinElmer Inc., China). The markers included Hepatitis B surface antigen (HBsAg), surface antibody (HBsAb) and core antibody (HBcAb). Previous findings provided us the patients with HBsAg negative/HBcAb positive. Collected serum samples from them were anonymized and tested for HBV DNA by real-time quantitative PCR assay. After 2 years follow-up, samples with persistent HBV DNA were determined the S regions by nested PCR, and sequence of gene mutation was compared with the standard sequence.

\section{HBV DNA testing}


$\mathrm{HBV}$ viral load (IU/ml) was measured using real-time polymerase chain reaction (qPCR) by COBAS AmpliPrep and COBAS TaqMan HBV Test (Roche, USA) according to the standard manufacturer's instructions. The qPCR kit has a detection limit of $20 \mathrm{IU} / \mathrm{ml}$.

\section{Nested PCR and sequencing}

PCR was carried out using PrimeSTAR Max DNA Polymerase (R045A, Takara, Japan) according to the protocol described. The mixtures were denatured at $98^{\circ} \mathrm{C}$ for $1 \mathrm{~min}$ and 30 cycles were performed in a thermal cycler. The PCR products were analyzed by electrophoresis on a $1.2 \%$ agarose gel. The sequences of the primers are 5'-GGGTCACCATATTCTTGGG -3 ' and 5'-CATACTTTCCAATCAATAGG -3 ' in the first PCR, and 5'-CTTGGGAACAAGATCTACAGC -3 ' and 5'-CATACTTTCCAATCAATAGG $-3^{\prime}$ in the second PCR. Amplified products were sequenced by Tsingke Biological Technology from China, and amino acid sequences were aligned with standard sequences from PubMed using BioEdit software (BioEdit Sequence Alignment Editor Software, Department of Microbiology, North California State University). Three standard sequences are from the previous studies[26-28].

\section{Statistical analysis}

All data were analyzed using SPSS 19.0 software (IBM Corp, NY, USA). Proportions were used to descriptive data. Measurement data is expressed as mean \pm SD. The comparison between the two groups was performed by $\chi^{2}$-test or Fisher's exact test. A $p$-value of less than 0.05 was used to determine whether relationships were statistically significant.

\section{Results}

\section{Relative characterization of MHD patients}

A total of 330 MHD-patients involved this study. Demographic characteristics of the dialysis population are shown in Figure 1 and 2 . The participants were aged 27 to 95 years [median \pm SD: $(60.66 \pm 14.32)$ years], with majority of patients were $>60$ years old (Figure 1 ). The proportion of male was $55.7 \%$ (185/330), and the female is $44.3 \%$ (145/330). The etiology of chronic kidney disease (CKD) and its proportion were listed in Figure 2. Chronic renal inflammatory disease, diabetic nephropathy (DN) and hypertension are major causes of CKD.

All the MHD-patients were determined the frequencies of HBV serological markers (HBsAg, HBsAb and $\mathrm{HBcAb}$ ) by ELISA. The results showed that the group of after immunizations via vaccination was $15.5 \%$ (51/330). 7.3\% (24/330) and 21.8\% (72/330) were the group non-immune and CHB infection, respectively. The significant proposition of past hepatitis $B$ infection was $54.5 \%$ (180/330). Less common 


\section{Assessment of HBV DNA among the studied MHD- patients}

Next, the 180 patients (54.5\%) were HBsAg negative but HBcAb positive and therefore considered to enroll the further study. Of those, 165 patients have given preoperative consent and collected serum sample to the HBV DNA testing. In many cases, serum (or plasma) HBV DNA determination and analysis based on real-time PCR has been used with sufficient sensitivity to detect OBI. Hence, we diagnosed OBI by serum HBV DNA[13]. The result suggested 7 patients (7/165) had low level of HBV DNA. For description in detail, we encoded them from No.1 to No.7 and their information showed in Table 2.

Five patients (No.1, 3, 4, 5 and 7) are both HBcAb and HBsAb positive, and 2 patients (No.2 and 6) are $\mathrm{HBCAb}$ positive alone. We followed these 7 patients for 2 years. Unfortunately, No.3 and 4 died within two years, so they couldn't continue the following study. Only No.2 and 6 remained low level of HBV DNA. But for the other 3 patients, HBV DNA turned to negative (Table 2). This result revealed that we should paid attention to patients with $\mathrm{HBcAb}$ positive alone.

\section{Nucleotide sequencing and phylogenetic analysis of the detected strains}

To explore the molecular mechanism of the phenomenon we observed in this study, we amplified and identified HBV DNA by nested PCR, and sequence of gene mutation was compared with the standard sequence. Amplified products were subjected to electrophoresis and analyzed. As with electrophoresis showed in Figure 3, No.2 and 6 remained the same bands as the positive control (No.8). More than 10 HBV genotypes (A to $\mathrm{J}$ ) and several subtypes have been implicated through the genetic divergence of the whole HBV genomic sequences [11]. We compared the two patients' sequence with standard sequence in PubMed. Findings revealed that both them were genotype B as previous studies described[2, 14].

Amino acid mutations related to vaccine escape, so we considered it to be a possible explanation of the continent HBV DNA. We compared their amino acid sequence with standard sequences (D00329, $A B 602818$ and $A B 073846$ ) using BioEdit. Results revealed No.2 did not occur any amino acid substitutions in "a" determinant. Otherwise, "a" determinant of No.6 had Q128R, T131N, M133S, F134L and D144E mutants (Table 2 and Figure 4). However, clinical implications of these mutations need further investigation.

\section{Discussion}


China is a high-prevalent area of hepatitis B infection. The incidence of HBV infection among hemodialysis patients in China was from $6.3 \%$ to $30.8 \%[3]$. OBI, a cause of HBV infection, should be taken seriously. However, the prevalence and the mutations of $\mathrm{OBI}$ in Sichuan province is rarely investigated. In total, 330 patients with maintenance hemodialysis were enrolled. We detected their serum using ELISA kit, and the result showed 7.3\% (24/330) patients were chronic HBV infection. Compared with other regions in China, the infection rate in our hospital was in a low level, indicating the protection was eligible. Interestingly, majority patients (165/330) were HBcAb positive but HBsAg negative, who were potentially $\mathrm{OBI}$ patients. when HBsAg is absent, $\mathrm{OBI}$ diagnosis is widely by analyzed low levels of the serum (or plasma) HBV-DNA (less than $200 \mathrm{IU} / \mathrm{mL}$ ) by real-time PCR assays $[7,13,29,30]$. Hence, the prevalence of $\mathrm{OBI}$ in our unit derived from HBV DNA screening. All the OBI patients were male. Man are more especially vulnerable to infect $\mathrm{OBI}$ than woman, which is consistent with the results of Kamal et al[31].

Prevalence of $\mathrm{CHB}$ and $\mathrm{OBI}$ were well-controlled in our unit, but several studies have shown that $\mathrm{OBI}$ leads to a higher risk of HBV transmission through blood exchange in maintenance hemodialysis patients[6]. Thus, regular screening of HBV DNA by sensitive PCR assays in MHD patients should be advocated.

We paid attention to the 7 persons and detected their HBV DNA again after 24months. Unfortunately, two individuals died so that we lost to follow-up. For the other patients, 3 of 5 individuals who were both $\mathrm{HBsAb}$ and HBcAb positive before turned to HBV DNA negative in 24 months. The other two patients with $\mathrm{HBCAb}$ positive alone were persistent HBV DNA positive within 24 months.

DNA extracts were amplified by highly sensitive nested PCR and then confirmed the nucleotide sequences. More than $10 \mathrm{HBV}$ genotypes (A to $\mathrm{J}$ ) and several subtypes have been implicated through the genetic divergence of the whole HBV genomic sequences [14].The two patients with HBcAb positive alone were both genotype $B$, which performed as previously described [2].

The HBsAg contains the major hydrophilic region (MHR) in the $S$ gene that spans amino acid positions 100 to 160 . The "a" determinant is a dominant epitope inside the MHR, which located between amino acids 124 and 147, and mutations in this region are related to the generation of vaccine escape variants and persistent infection[8,32-35]. HBV pre-S/S gene mutations influence the immune escape of hepatitis $B$ immunoglobulin. Mutations in the pre-S, core promoter and $S$ regions also promote the progress of cirrhosis and HCC[14]. Actually, "a" determinant is more vital for immune response to HBV infection, and amino acid substitution in this region can generate escape mutations and result in OBI[36, 37]. Thus, sequence analysis identified mutations in "a" determinant from patients with persistent HBV DNA positive. G145R mutant occurred most commonly during $\mathrm{OBI}[6,22,24]$, which have mainly been found in genotype B [33]. But sequences alignment of two patients did not show G145R mutant.

We found mutations of Q128R, T131N, M133S, F134L and D144E from one patient. Position of T131N, F134L and D144E had been reported[19-21, 23], but Q128R and M133S have not been determined. The new amino acid changes we identified might be significantly reduced the specific anti-HBs antibodies binding. 
The clinical implications and mechanism of OBI remain poorly understood. Except mutations in the "a" determinant of HBsAg, treatment-associated mutations, splicing and mutations in the pre-S region also associated with $\mathrm{OBI}[10]$. For further understanding, mechanisms linked to host immune response, such as vitamin $\mathrm{D}$ receptor polymorphisms (VDR), cytolytic and noncytolytic T-cell responses, and apoptosis, are related to the regulation of HBV replication and protein synthesis[10]. In addition, it has been reported that memory T-cell immune response, innate immune system or cytokines such as tumor necrosis factor$a$ and interferon- $y$ are also associated with OBI [13]. In vivo, the injection of specific vtHBsAg could identify the effect of amino acid substitution. At present, K122I, G145R/I/W/E, and others, are found in the "a" determinant to damage HBsAg secretion, antibody binding and immune escape[38].

In our study, we found new positions related to OBI from reliable patients. Further studies both in vivo and in vitro should be considered in our experiment to verify the significant mutants and clinical implications.

\section{Conclusions}

The prevalence of $\mathrm{CHB}$ and $\mathrm{OBI}$ was well controlled in our unit, but we also advocate the regular screening of HBV DNA to prevent the serious complications. Mutants of Q128R and M133S were novel and their clinical implication should be further studied.

\section{Abbreviations}

$\mathrm{OBI}$ occult hepatitis $\mathrm{B}$ virus infection

MHD maintenance hemodialysis

HBV hepatitis B virus

CHB chronic hepatitis B

HBsAg Hepatitis B surface antigen

HBsAb Hepatitis B surface antibody

HBcAb Hepatitis B core antibody

PCR polymerase chain reaction

HCC hepatocellular carcinoma

HD hemodialysis

MHR main hydrophilic region

SD standard deviation 
DN diabetic nephropathy

CKD chronic kidney disease

VDR vitamin D receptor

\section{Declarations}

\section{Ethics approval and consent to participate}

The study has been granted by ethics committee of Sichuan provincial people's hospital (Grant No. 2017120). Written informed consent for the study was obtained from all patients.

\section{Consent for publication}

No applicable.

\section{Availability of data and materials}

The datasets used and/or analysed during the current study are available from the corresponding author on reasonable request.

\section{Competing interests}

The authors declare that they have no competing interests.

\section{Funding}

This work was supported by Chinese Hospital Association Foundation (No. CHABP2016-12) and Wu Jieping Medical Foundation (No. 320.6750.16193). The corresponding author is the leader of the two projects from Chinese Hospital Association Foundation and Wu Jieping Medical Foundation which provided research funds.

\section{Authors' contributions}

YT analysed the experimental data, and was a major contributor in writing the manuscript. XQL examined the serological assessment. DH collected information of patients. XHL analysed patients' information. 
QH and GL made contribution to collected samples from patients. YZ designed and fund this work. All authors read and approved the final manuscript.

\section{Acknowledgements}

Authors thank Prof. Shaoping Deng and Prof. Zhenglin Yang in University of Electronic Science and Technology, Sichuan Academy of Medical Sciences \& Sichuan Provincial People's Hospital for generously providing research platforms and technical support.

\section{References}

1.Yonghao G, Jin X, Jun L, Pumei D, Ying Y, Xiuhong F, Yanyang Z, Wanshen G: An epidemiological serosurvey of hepatitis $B$ virus shows evidence of declining prevalence due to hepatitis $B$ vaccination in central China. International Journal of Infectious Diseases 2015, 40:75-80.

2.Yu R, Fan R, Hou J: Chronic hepatitis B virus infection: epidemiology, prevention, and treatment in China. Front Med 2014, 8(2):135-144.

3.Wang C, Sun J, Zhu B, Larsen S, Yu R, Wu J, Zhao W: Hepatitis B virus infection and related factors in hemodialysis patients in China - systematic review and meta-analysis. Ren Fail 2010, 32(10):1255-1264.

4.Eleftheriadis T, Liakopoulos V, Leivaditis K, et al: Infections in hemodialysis: a concise review. Part II: blood transmitted viral infections. Hippokratia, 2011, 15(2):120-6.

5.Hoofnagle J H, Seeff L B, Bales Z B, et al: Type B Hepatitis after Transfusion with Blood Containing Antibody to Hepatitis B Core Antigen. N Engl J Med, 1978, 298(25):1379-1383.

6.Besharat S, Katoonizadeh A, Moradi A: Potential mutations associated with occult hepatitis B virus status. Hepat Mon 2014, 14(5):e15275.

7.Torbenson M, Thomas DL: Occult hepatitis B. The Lancet Infectious Diseases 2002, 2(8):479-486.

8.Kim H, Kim B-J: Association of preS/S Mutations with Occult Hepatitis B Virus (HBV) Infection in South Korea: Transmission Potential of Distinct Occult HBV Variants. International Journal of Molecular Sciences 2015, 16(12):13595-13609.

9.Wen X, Su H, Wang Y, Pu Z, Gao J, Ji Z, Yuan X, Li X, Zhang W, Zhang L et al: Prevalence and natural course of occult hepatitis $B$ virus infection in residents of 2 communities of Wuwei City, Gansu Province, China. J Viral Hepat 2018, 25(3):281-288.

10.Samal J, Kandpal M, Vivekanandan P: Molecular mechanisms underlying occult hepatitis $B$ virus infection. Clin Microbiol Rev 2012, 25(1):142-163. 
11.Abdel-Maksoud NHM, El-Shamy A, Fawzy M, Gomaa HHA, Eltarabilli MMA: Hepatitis $B$ variants among Egyptian patients undergoing hemodialysis. Microbiol Immunol 2019, 63(2):77-84.

12.Eleftheriadis T, Liakopoulos V, Leivaditis K, et al: Infections in hemodialysis: A concise review - part 1: Bacteremia and respiratory infections. Hippokratia, 2011, 15(1):12-17.

13.Kwak MS, Kim YJ: Occult hepatitis B virus infection. World J Hepatol 2014, 6(12):860-869.

14.Lin CL, Kao JH: Natural history of acute and chronic hepatitis B: The role of HBV genotypes and mutants. Best Pract Res Clin Gastroenterol 2017, 31(3):249-255.

15.Candotti D, Grabarczyk P, Ghiazza P, Roig R, Casamitjana N, ludicone P, Schmidt M, Bird A, Crookes R, Brojer E et al: Characterization of occult hepatitis $B$ virus from blood donors carrying genotype $A 2$ or genotype D strains. J Hepatol 2008, 49(4):537-547.

16.Tong W, Sun L, He J, et al: A novel nucleotide insertion in S gene of hepatitis $B$ virus in a chronic carrier. Virol J, 2010, 7(1):104.

17.Darmawan E, Turyadi, El-Khobar KE, Nursanty NK, Thedja MD, Muljono DH: Seroepidemiology and occult hepatitis B virus infection in young adults in Banjarmasin, Indonesia. J Med Virol 2015, 87(2):199207.

18.Oliveira MP, Lemes PS, Matos MA, Del-Rios NH, Carneiro MA, Silva AM, Lopes CL, Teles SA, Aires RS, Lago BV et al: Overt and occult hepatitis B virus infection among treatment-naive HIV-infected patients in Brazil. J Med Virol 2016, 88(7):1222-1229.

19.Song EY, Yun YM, Park MH, Seo DH: Prevalence of occult hepatitis $B$ virus infection in a general adult population in Korea. Intervirology 2009, 52(2):57-62.

20.Ababneh NA, Sallam M, Kaddomi D, Attili AM, Bsisu I, Khamees N, Khatib A, Mahafzah A: Patterns of hepatitis $B$ virus $S$ gene escape mutants and reverse transcriptase mutations among genotype $D$ isolates in Jordan. PeerJ 2019, 7:e6583.

21.Salpini R, Colagrossi L, Bellocchi MC, Surdo M, Becker C, Alteri C, Aragri M, Ricciardi A, Armenia D, Pollicita $\mathrm{M}$ et al: Hepatitis $B$ surface antigen genetic elements critical for immune escape correlate with hepatitis B virus reactivation upon immunosuppression. Hepatology 2015, 61(3):823-833.

22.Rezaee R, Poorebrahim M, Najafi S, Sadeghi S, Pourdast A, Alavian SM, Alavian SE, Poortahmasebi V: Impacts of the G145R Mutation on the Structure and Immunogenic Activity of the Hepatitis B Surface Antigen: A Computational Analysis. Hepat Mon 2016, 16(7):e39097.

23.Hou J, Wang Z, Cheng J, Lin Y, Lau GK, Sun J, Zhou F, Waters J, Karayiannis P, Luo K: Prevalence of naturally occurring surface gene variants of hepatitis $B$ virus in nonimmunized surface antigen-negative Chinese carriers. Hepatology 2001, 34(5):1027-1034. 
24.Shahmoradi S, Yahyapour Y, Mahmoodi M, Alavian SM, Fazeli Z, Jazayeri SM: High prevalence of occult hepatitis $B$ virus infection in children born to HBsAg-positive mothers despite prophylaxis with hepatitis B vaccination and HBIG. J Hepatol 2012, 57(3):515-521.

25.Koyanagi T, Nakamuta M, Sakai $\mathrm{H}$, et al: Analysis of HBs antigen negative variant of hepatitis $B$ virus: unique substitutions, Glu129 to Asp and Gly145 to Ala in the surface antigen gene. Med Sci Monit, 2000, 6(6):1165-1169.

26.Okamoto H, Tsuda F, Sakugawa H, et al: Typing Hepatitis B Virus by Homology in Nucleotide Sequence: Comparison of Surface Antigen Subtypes. J Gen Virol, 1988, 69(10):2575-2583.

27.Sugauchi F, Orito E, Ichida T, Kato H, Sakugawa H, Kakumu S, Ishida T, Chutaputti A, Lai CL, Ueda R et al: Hepatitis $B$ virus of genotype $B$ with or without recombination with genotype $C$ over the precore region plus the core gene. J Virol 2002, 76(12):5985-5992.

28.Inoue J, Ueno Y, Wakui Y, Fukushima K, Kondo Y, Kakazu E, Ninomiya M, Niitsuma H, Shimosegawa T: Enhanced replication of hepatitis $B$ virus with frameshift in the precore region found in fulminant hepatitis patients. J Infect Dis 2011, 204(7):1017-1025.

29.Bruni R, Prosperi M, Marcantonio C, et al: A computational approach to identify point mutations associated with occult hepatitis $B$ : significant mutations affect coding regions but not regulative elements of HBV. Virol J, 2011, 8(1):394-394.

30.Ye X, Li T, Xu X, Du P, Zeng J, Zhu W, Yang B, Li C, Allain JP: Characterisation and follow-up study of occult hepatitis $B$ virus infection in anti-HBc-positive qualified blood donors in southern China. Blood Transfus, 2017, 15(1):6-12.

31.Dumaidi K, Al-Jawabreh A: Prevalence of occult HBV among hemodialysis patients in two districts in the northern part of the West Bank, Palestine. J Med Virol 2014, 86(10):1694-1699.

32.Zuckerman AJ: Effect of hepatitis B virus mutants on efficacy of vaccination. The Lancet 2000, 355(9213):1382-1384.

33.Amini-Bavil-Olyaee S, Vucur M, Luedde T, Trautwein C, Tacke F: Differential impact of immune escape mutations $G 145 R$ and $P 120 T$ on the replication of lamivudine-resistant hepatitis $B$ virus e antigenpositive and -negative strains. J Virol 2010, 84(2):1026-1033.

34.Banerjee A, Chandra PK, Datta S, Biswas A, Bhattacharya P, Chakraborty S, Chakrabarti S, Bhattacharya SK, Chakravarty R: Frequency and significance of hepatitis $B$ virus surface gene variant circulating among 'antiHBc only' individuals in Eastern India. J Clin Virol 2007, 40(4):312-317.

35.Lada O, Benhamou Y, Poynard T, Thibault V: Coexistence of hepatitis B surface antigen (HBs Ag) and anti-HBs antibodies in chronic hepatitis B virus carriers: influence of "a" determinant variants. J Virol 2006, 80(6):2968-2975. 
36.Rastegarvand N, Makvandi M, Samarbafzadeh A, Rasti M, Neisi N, Pouremamali A, Teimoori A, Shabani A: Molecular Characterization of Pre-Core/Core and S Region of Hepatitis B Virus in Hemodialysis Patients With Occult Hepatitis B Infection. Jundishapur J Microbiol 2015, 8(10):e23686.

37.Nainan OV, Khristova ML, Byun K, Xia G, Taylor PE, Stevens CE, Margolis HS: Genetic variation of hepatitis $B$ surface antigen coding region among infants with chronic hepatitis $B$ virus infection. $J$ Med Virol 2002, 68(3):319-327.

38.Wu C, Deng W, Deng L, Cao L, Qin B, Li S, Wang Y, Pei R, Yang D, Lu M et al: Amino acid substitutions at positions 122 and 145 of hepatitis B virus surface antigen (HBsAg) determine the antigenicity and immunogenicity of HBsAg and influence in vivo HBsAg clearance. J Virol 2012, 86(8):4658-4669.

\section{Tables}

Table 1. Hepatitis B status of our hemodialysis unit.

\begin{tabular}{|c|c|c|c|c|}
\hline & $\begin{array}{l}\text { Hepatitis B surface antigen } \\
\text { (HBsAg) }\end{array}$ & $\begin{array}{l}\text { Hepatitis B core antibody (anti- } \\
\text { HBcAb) }\end{array}$ & $\begin{array}{l}\text { Hepatitis B surface antibody(anti- } \\
\text { HBsAb) }\end{array}$ & $\begin{array}{l}\text { Number } \\
\text { of } \\
\text { patients }\end{array}$ \\
\hline $\begin{array}{l}\text { HBV immune via } \\
\text { vaccination }\end{array}$ & Negative & Positive & Negative & $\begin{array}{l}55 \\
(15.5 \%)\end{array}$ \\
\hline Chronic HBV infection & Positive & Negative & Positive & $24(7.3 \%)$ \\
\hline Past Hepatitis B & Negative & Positive & Positive & $\begin{array}{l}147 \\
(44.5 \%)\end{array}$ \\
\hline \multicolumn{5}{|l|}{ infection } \\
\hline $\begin{array}{l}\text { Past Hepatitis B } \\
\text { infection* }\end{array}$ & Negative & Negative & Positive & $33(10 \%)$ \\
\hline Non-immune & negative & Negative & Negative & $\begin{array}{l}72 \\
(21.8 \%)\end{array}$ \\
\hline $\begin{array}{l}\text { Early stage of HBV } \\
\text { infection }\end{array}$ & Positive & Positive & Positive & $3(0.9 \%)$ \\
\hline
\end{tabular}

*Patients who have acquired natural immunity due to prior exposure to hepatitis B

Table 2. Characteristics and information of OBI patients.

\begin{tabular}{lllllllll}
\hline Code & Sex & $\begin{array}{l}\text { Age- } \\
\text { ranges }\end{array}$ & HBsAg & HBsAb & HBcAb & $\begin{array}{l}\text { HBV-DNA } \\
\text { (IU/ml) }\end{array}$ & $\begin{array}{l}\text { HBV-DNA (2 years } \\
\text { follow-up) }\end{array}$ & Mutations in "a” determinant \\
\hline $\mathbf{1}$ & Male & $60-69$ & Negative & Positive & Positive & $<20$ & Negative & Unknown \\
\hline $\mathbf{2}$ & Male & $70-69$ & Negative & Negative & Positive & $<20$ & $<20$ & No mutation \\
\hline $\mathbf{3}$ & Male & $60-69$ & Negative & Positive & Positive & $<20$ & Died & Unknown \\
\hline $\mathbf{4}$ & Male & $80-89$ & Negative & Positive & Positive & $<20$ & Died & Unknown \\
\hline $\mathbf{5}$ & Male & $60-69$ & Negative & Positive & Positive & $<20$ & Negative & Unknown \\
\hline $\mathbf{7}$ & Male & $60-69$ & Negative & Negative & Positive & $<20$ & $<20$ & Q128R, T131N, M133S, F134L, \\
\hline
\end{tabular}


Figures

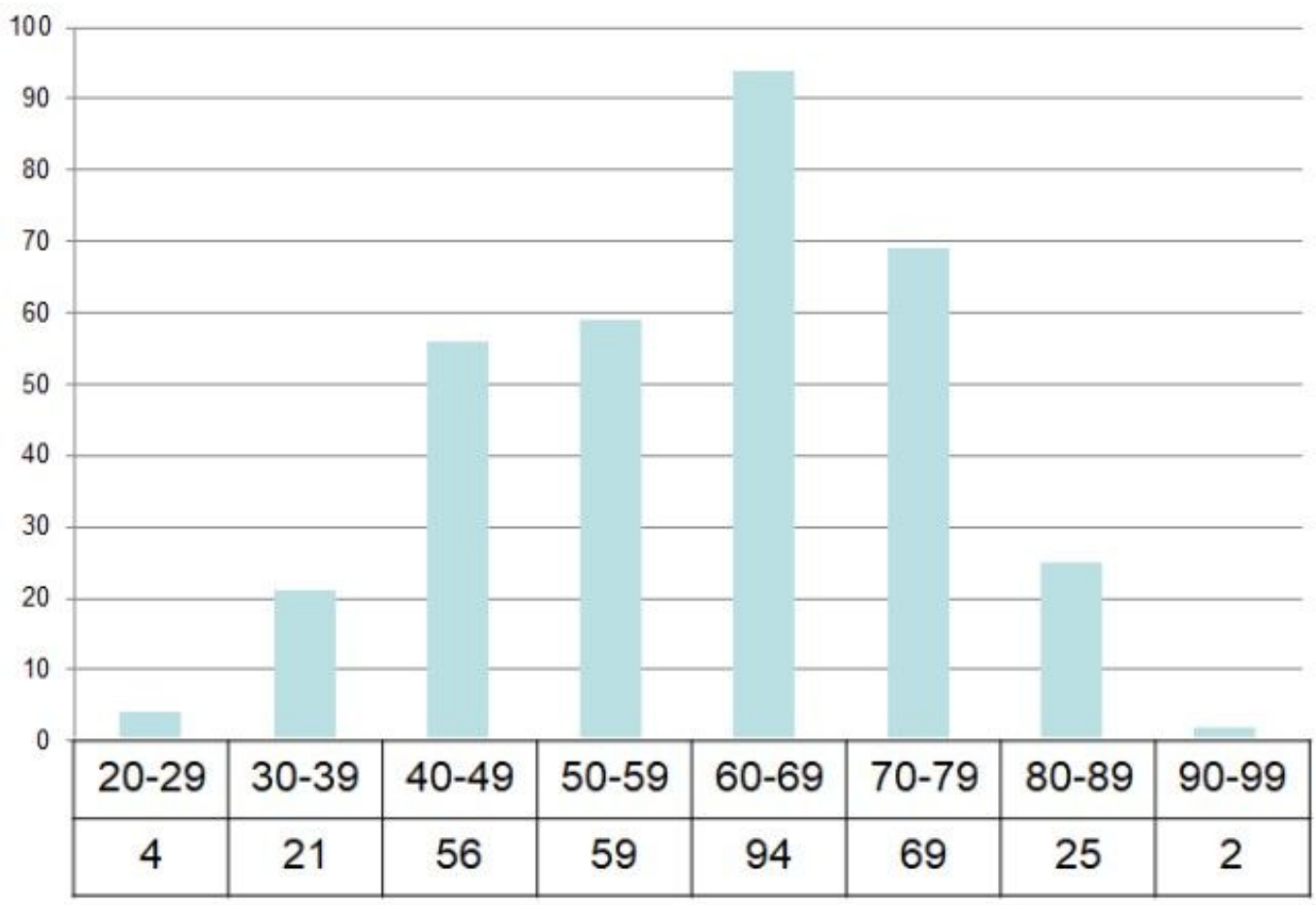

Figure 1

Distribution of patients age. 


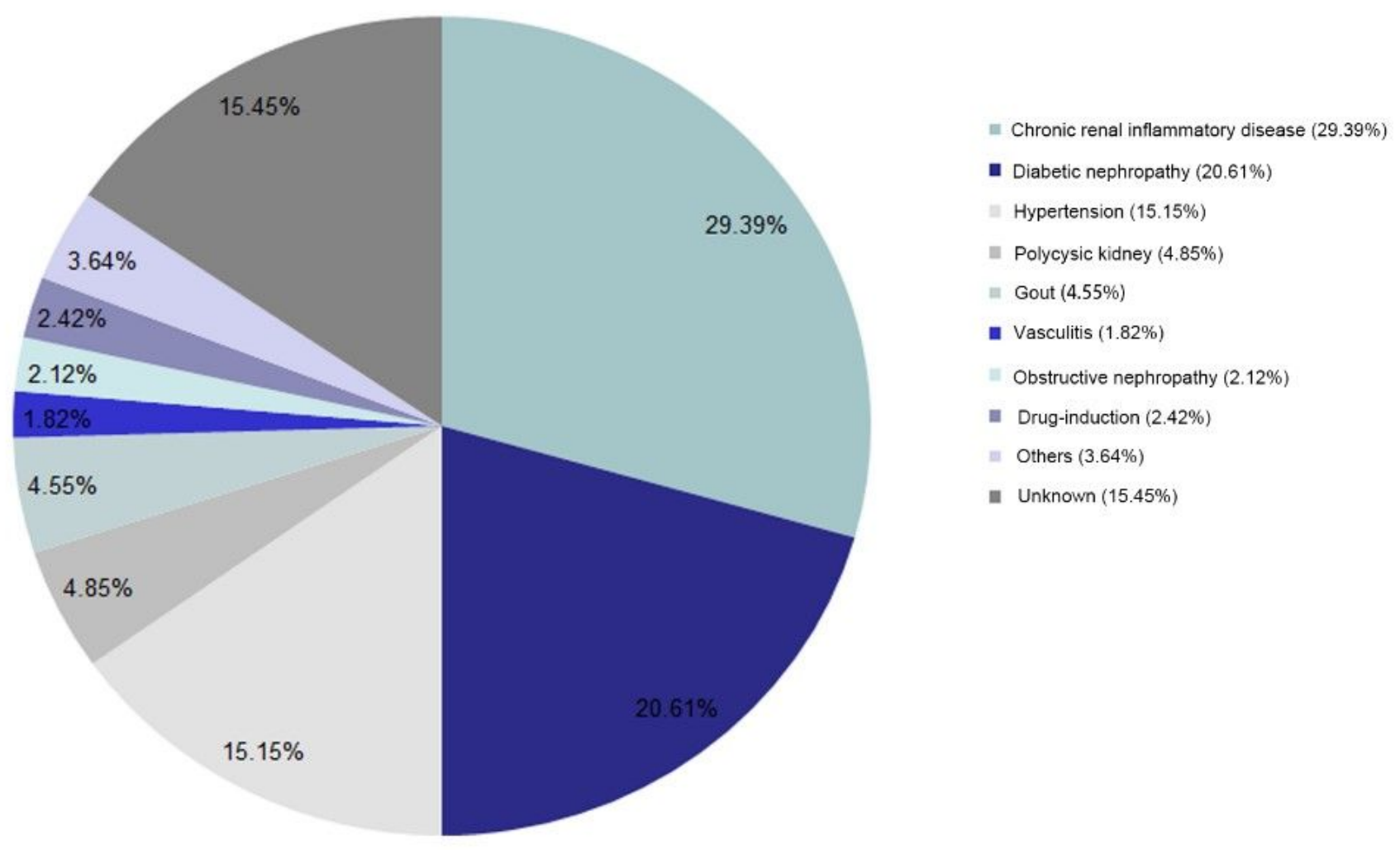

Figure 2

The etiology of CKD and its proportion in MHD patients.

A

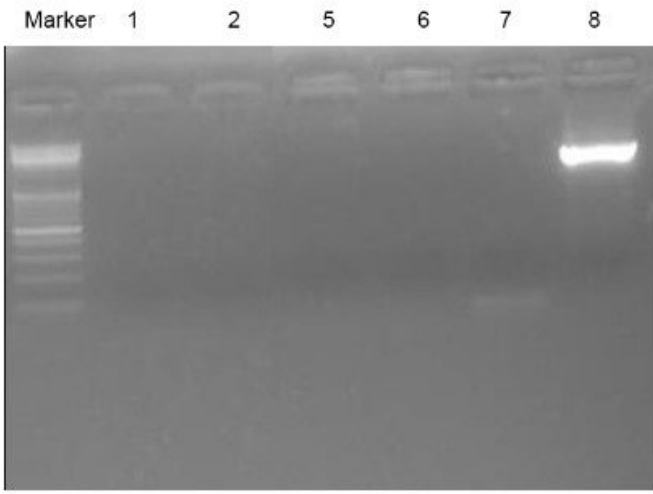

B

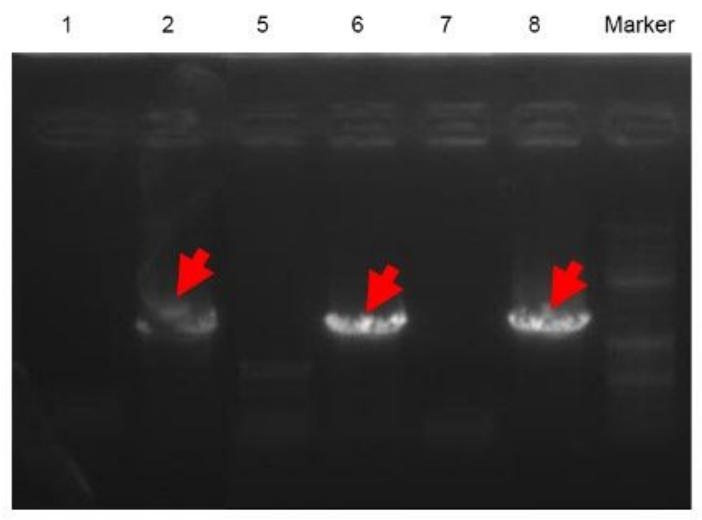




\section{Figure 3}

Nested PCR of follow-up patients. (A) The first PCR. (B) The second PCR. No.8 was positive control. The arrow showed positive result.

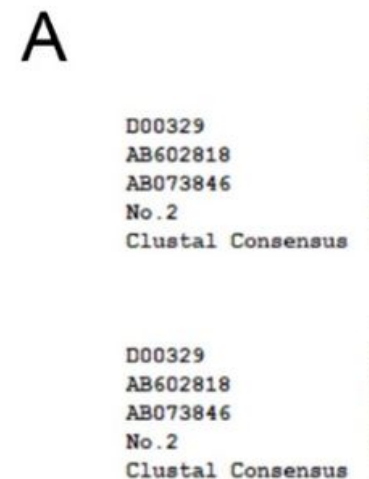

B

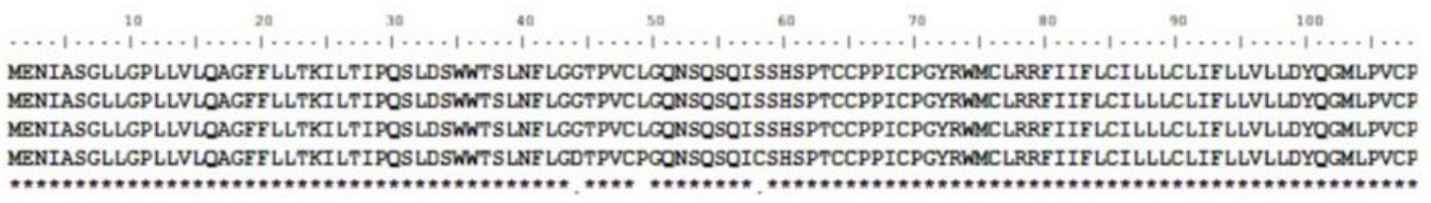

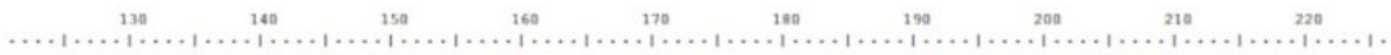

CKTCTTPAOGT SMFPSCCCTKPMDGNCTCIPIPSSWAFAKYLWEWASVRFSWLSLLVPFVWFVGLSPTVWLSVIWAOWYGPSLYNILSPFMPLLPIFFCLWVY CKTCTTPAOGTSMEPSCCCTKPTDGNCTCIPIPSSWAFAKYLWEWASVRESWLSLLVPFVOWEVGLSPTVWLSVIWMOYWGPSLYNILSPFMPLLPIFFCLWVI CKTCTTPAOGT SMF PSCCCTKPTDGNCTCIPIPSSWAFAKYLWEWASVRE SWLSLLVPFVOWEVGLSPTVWLSVIWAAYWGPSLYNI LSPFMPLLPIFFCLWVYI CKTCTTPAOGT SMFPSCCCTKPTDCNCTCIPIPSSWAFAKYLWEWASVRE SWLSLLVPFVWEVGLSPTVWLSVIWMATWGPSLYNI LSPRMPLLPLFFCLWVYI

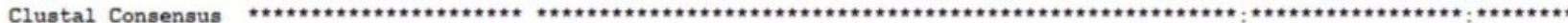

\section{D00329}

AB602818

AB073846

No. 6

Clustal Consensus

D00329

AB602818

AB073846

No. 6

Clustal Consensus

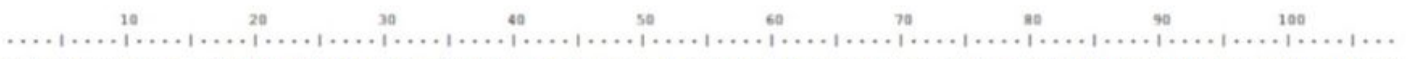
MENIASGLLGPLLVLOAGFFLTKI LTIPOSLDSWTTSLNFLGGTPVCLCONSOSOISSHSPTCCPPICPGYRWMCLRRFIIFLCILLLCLIFLLVLLDYOCMLPVCP MENIASGLLGPLLVLOAGFFLLTKI LTIPOSLDSWTS LNF LGGTPVCLCONSOSOISSHSPTCCPPICPGYRWCLRRFIIFLCILLLCLIFLLVLLDYOCMLPVCP MENIASGLLGPLLVLOAGFFLLTKILTIPOSLDSWWTSLNFLGCTPVCLCONSOSOISSHSPTCCPPICPGYRWCLRRFIIFLCILLLCLIFLLVLLDYOCMLPVCP MENIASGLLGPLLALOAVFFLLTKI LTIPOSLDSWWT SLNFLGETPVCLCOSSOSOISSHSPTCCPPICPGYRWMCLRRFIIFLCI LLLCLIFSLVLLDYHCMLPVCF

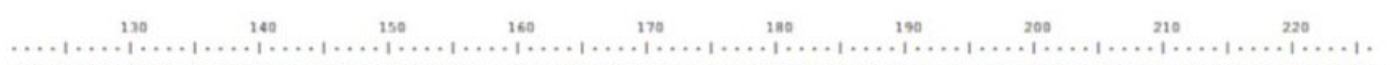
CKTCTTPAOGTSMFPSCCCTKPMDGNCTCIPIPSSWAFAKYLWEWASVRFSWLSLLVPFVOWFVGLSPTVWLSVIWMOYWGPSLYNI LSPFMPLLPIFFCLWVYI CKTCTTPAOGTSMFPSCCCTKPTDGNCTCIPIPSSWAFAKYLWEWASVRF SWLSLLVPFVOWFVGLSPTVWLSVIWMWYWGPSLYNI LSPFMPLLPIFFCLWVYI CKTCTTPAOGT SMFPSCCCTKPTDGNCTCIPIPSSWAFAKYLWEWASVRFSWLSLLVPFVWWVGLSPTVWLSVTWAAYYGPSLYNI LSPFMPLLPIFFCLWVYI CRTCTTPARGNSSLPSCCCTKPTECNCTCIPIPSSWAFVKYLWEWASVRSSWLSLLVPFVOWFAELSPTVWLSVIWAWYWGPRLCNILSPFIPLLPIFCCLWAYT

\section{Figure 4}

The mutations in "a" determinant of No.2 and No.6 compared with standard sequences. (A) No.2 patient had no mutations in "a" determinant. (B) No.6 patient had Q128R, T131N, M133S, F134L and D144E mutants. 